\title{
An evaluation of road traffic emissions around Galician cities
}

\author{
M. Dios, M. S. Castro, J. A. Souto \& J. J. Casares \\ Department of Chemical Engineering, Spain
}

\begin{abstract}
Road transport emissions have straightforward effects on air quality requirements, at local, regional and even global scales. Nowadays, almost all of motor vehicles use fossil fuels that, within their use, produce emissions of a same range of pollutants, although the amount and ratio are different according to the fuel, type of vehicle and combustion conditions. This fact is especially important in saturated roads, because vehicles caught in traffic jams are at the most polluting scenario, in comparison with regular use of a vehicle. Due to the importance of these emissions and trying to enforce legal specifications, technological improvements are installed on vehicles, which allow one to reduce emissions, as well as fuel consumption. These aspects are thought as the main issue in sustainable development in road transport around cities.

The main aim of this work is to calculate and analyze contributions of the Atlantic Highway within Galicia, NW of Spain, to the road traffic pollution in the cities connected by it. The highway considered, covers more than $220 \mathrm{~km}$ from the NW to the SW of the region, and connects several major cities in Galicia. A standard methodology for estimation of road traffic was applied, based on EMEP/CORINAIR (Emission Inventory Guidebook 2007 Technical Report No. 16/2007. European Environment Agency EEA, 2007). To guarantee consistence and comparability of the results obtained, COPERT 4 (Computer Programme to Calculate Emissions from Road Traffic) was chosen. The pollutants considered were $\mathrm{CO}, \mathrm{NO}_{\mathrm{x}}, \mathrm{NMVOC}, \mathrm{SO}_{\mathrm{x}}, \mathrm{NH}_{3}, \mathrm{GHG}$ and particles, and the reference year is 2006 .

To assess the importance of highway emissions, it was necessary to calculate emissions from regular traffic in neighbouring areas. For comparison purposes, the present work focus on EMEP grid cells crossed by the highway. Cells are $(49,14),(49,15),(49,16),(49,17),(50,13)$ and $(50,14)$. Evaluation of EMEP cells
\end{abstract}


emissions allow us to verify the importance of traffic in the cities involved, and major differences were encountered.

Keywords: road traffic emissions, highway, EMEP/CORINAIR, COPERT.

\section{Introduction}

Road traffic emissions pose significant pressure over the environment. In the last 20 years, several measures have been taken to reduce emissions: improvements on the technology of the vehicles' engines, the introduction of cleaner fuels or emission control systems. Despite these measures, many cities are still facing air quality problems. Population of the cities are, in general, exposed to high concentration of pollutants, due to emissions from roads are closer to the general public than, for instance, industrial emissions [3].

Present vehicles are more than an order of magnitude cleaner than 20 years ago, but the contribution to atmospheric emissions from transport keeps growing [1], for instance, in 2005 road traffic was estimated to contribute to $14.7 \%$ of total GHG emissions and $42 \%$ of total $\mathrm{NO}_{\mathrm{x}}$. This is because of the growth in transport volume, which has not been followed by effective measures.

Taking into account the diversity in road vehicles, the calculation procedure of emissions is complicated, and requires the compilation of statistical activity data. Due to the large number of influential factors: driving conditions, climatic conditions, vehicle age and mileage, etc, it is necessary to evaluate the emissions in a systematic manner. This was done by means of COPERT 4, which is a package widely used and accepted in Europe and its methodology is fully consistent with the Road Transport chapter of the EMEP/CORINAIR Emission Inventory Guidebook $[1,2]$.

The main aim of this work was to estimate the pollutant emissions generated by the Atlantic Highway in 2006, and its contribution to the emissions of the major cities connected by it: Vigo, A Coruña and Santiago de Compostela. Therefore, COPERT 4 methodology was applied to calculate emissions from the Atlantic Highway, and also from the EMEP grid cells crossed by the highway.

The results of the study constitute a basis for comparison with EMEP inventory data [4] and permit the analysis of the contributions of the highway within the area considered.

\section{Scope and traffic data}

\subsection{Pollutants considered and time horizon}

This work considers the following air pollutants: $\mathrm{CO}, \mathrm{NO}_{\mathrm{x}}, \mathrm{NMVOC}, \mathrm{SO}_{\mathrm{x}}, \mathrm{NH}_{3}$, $\mathrm{GHG}\left(\mathrm{CO}_{2}, \mathrm{CH}_{4}\right.$ and $\left.\mathrm{N}_{2} \mathrm{O}\right)$ and particles (as total particulate matter).

The base year chosen was 2006 .

\subsection{Geographic domain}

The Atlantic Highway is the main highway of Galicia and covers approximately $220 \mathrm{~km}$ from the northwest to the southwest of the region, joining the major 


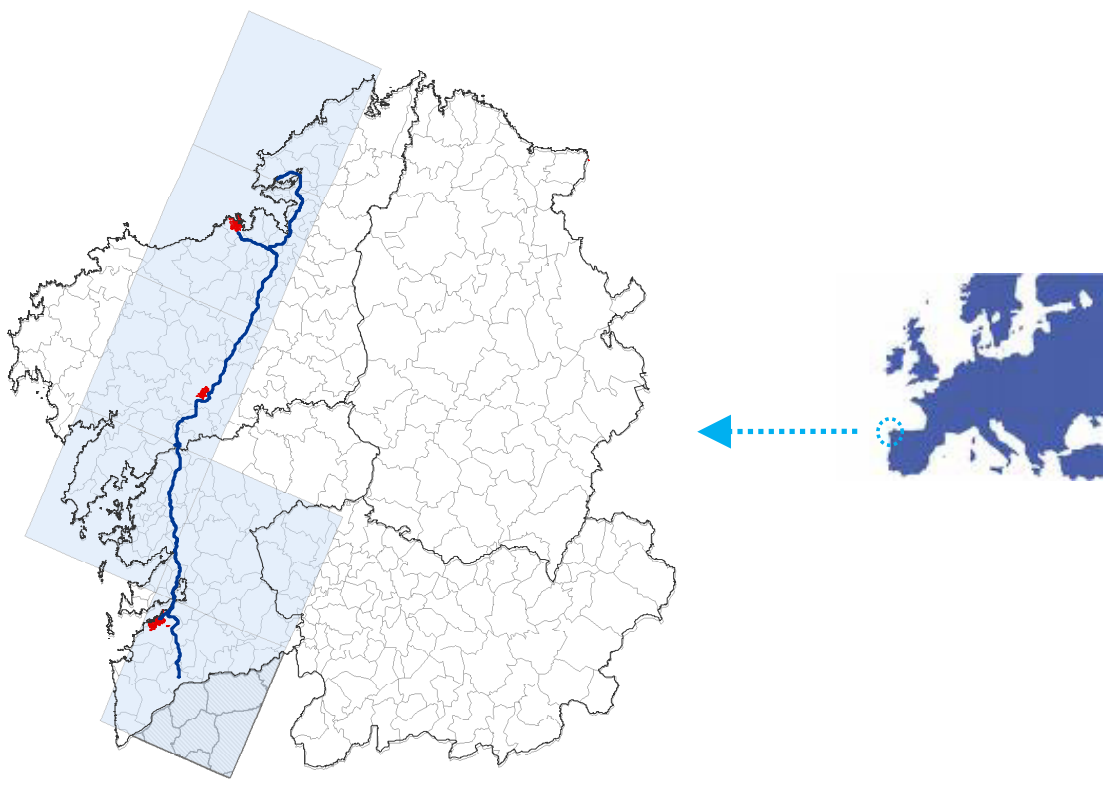

Figure 1: $\quad$ EMEP grid over Galicia (NW of Spain). Highlighted EMEP grid cells under study, Atlantic Highway and major cities, from north to south: a Coruña, Santiago de Compostela and Vigo.

cities: Vigo, A Coruña and Santiago de Compostela (295000, 245000 and 100000 inhabitants respectively). This highway goes through the following EMEP grid cells: $(49,14),(49,15),(49,16),(49,17),(50,13)$ and $(50,14)$, see Figure 1.

\subsection{Traffic data}

Attending to traffic data, it was necessary to differentiate between two complementary situations: the regular traffic within the area defined by EMEP grid cells and the Atlantic Highway:

- The regular traffic takes place mainly in urban and rural roads; and it is compounded of the registered fleet of vehicles of the area. This fleet of vehicles has an average annual mileage, which can be drawn from statistical data for the different types of vehicles considered.

- The analysis of highway traffic is different, because both the fleet of vehicles and mileage are clearly defined: the fleet of vehicles is monitored with vehicle traffic counters every few kilometres; and each vehicle in circulation covers partially or totally the length of the highway.

These facts mean that emission calculation must be performed in an independent way for both situations. 


\subsubsection{Regular traffic}

The registered fleet of vehicles data were compiled for each municipality affected $[5,6]$. In those municipalities which are partially affected, data were distributed attending to spatial factors. The registered fleet of vehicles for each EMEP grid cell is presented in Table 1, where the following types of vehicles were identified: passenger cars, light duty vehicles LDV, heavy duty vehicles HDV, buses and motorcycles:

Table 1: $\quad$ Number of vehicles on EMEP cells for the various types described.

\begin{tabular}{|c|c|c|c|c|c|}
\hline EMEP cell & Passenger Cars & LDV & HDV & Buses & Motorcycles \\
\hline 49,14 & 58294 & 6207 & 393 & 146 & 3036 \\
\hline 49,15 & 235258 & 31148 & 1970 & 771 & 14065 \\
\hline 49,16 & 114076 & 18041 & 1141 & 454 & 5844 \\
\hline 49,17 & 128695 & 21619 & 1369 & 333 & 8652 \\
\hline 50,13 & 108614 & 14346 & 908 & 250 & 5897 \\
\hline 50,14 & 305399 & 53904 & 3414 & 897 & 25896 \\
\hline$\Sigma$ & 950336 & 145265 & 9195 & 2851 & 63390 \\
\hline
\end{tabular}

\subsubsection{The Atlantic Highway}

In respect of the highway, official traffic counters information was compiled [7]. The traffic intensity along the highway is highly variable; therefore, it was

\begin{tabular}{|c|c|c|c|}
\hline & Stretch & Vehicles/day & \% heavy traffic \\
\hline $\mathrm{H}-1$ & 54319 & 5,88 \\
\hline $\mathrm{H}-2$ & 29318 & 9,07 \\
\hline $\mathrm{H}-3$ & 18059 & 9,59 \\
\hline $\mathrm{H}-4$ & 34602 & 11,57 \\
\hline $\mathrm{H}-5$ & 19227 & 11,86 \\
\hline $\mathrm{H}-6$ & 36140 & 11,49 \\
\hline $\mathrm{H}-7$ & 57226 & 7,21 \\
\hline $\mathrm{H}-8$ & 33742 & 8,85 \\
\hline $\mathrm{H}-9$ & 33700 & 8,85 \\
\hline
\end{tabular}

Figure 2: Distribution of traffic over the Atlantic Highway. 
necessary to split up the highway in 14 stretches with similar traffic intensity values (Figure 2). Other determining factor was the proportion of heavy traffic, which is quite significant in some stretches of the highway. It is important to highlight traffic intensity in the approaches to the cities.

\section{Description of the methodology applied}

Emissions of road transport are calculated as the sum of the emissions of all vehicular traffic, as it is shown here:

$$
E_{i}=\sum_{i, j} N_{j} \cdot L_{j} \cdot F E_{i, j}
$$

where $\mathrm{E}_{\mathrm{i}}$ denotes the emission for pollutant $\mathrm{i}(\mathrm{kg} / \mathrm{year})$; $\mathrm{N}$ denotes the number of vehicles segment $j$; $L_{j}$ denotes the annual mileage of vehicle segment $j$; and $\mathrm{FE}_{\mathrm{i}, \mathrm{j}}$ denotes the emission factor for pollutant $\mathrm{i}$ and vehicle segment $\mathrm{j}$.

In eqn. (1), emission factors are specific for each one of the vehicles segments, which are establish according to the following factors [8]: climatic conditions, fuel type, vehicle types, technical characteristics of the vehicles and driving conditions.

\subsection{Application of the methodology}

The study focuses on the compilation of the data required for the area under study. The compilation and processing of input data for COPERT 4 are shown briefly below:

\subsubsection{Climatic conditions}

As input data, monthly minimum and maximum temperatures are required. The area under study covers a great surface from northwest to southwest of Galicia. Due to the size of the area considered, it is necessary to calculate mean values for the temperatures from all meteorological stations placed within the area [9].

\subsubsection{Vehicle category split}

In the first place, the vehicle fleet can be split in the already mentioned categories: passenger cars, light duty vehicles LDV, heavy-duty vehicles HDV, buses, and motorcycles. These main categories are also split according to the fuel type used; the year of vehicle production which defines the technology implemented in the vehicle for achieving the emissions standards; and also other specific characteristics: engine capacity, maximum weight, etc. [5]

The categorization published by official institutions does not correspond with that required by COPERT 4; therefore, a detailed classification following the aforementioned parameters was constructed:

- For regular traffic within EMEP grid cells considered, the registered fleet of vehicles of the area is used in combination with statistical data about 
consumption of fuel, capacity of engine, maximum weight (LDV an HDV), etc $[5,10,11]$.

- For the highway vehicles, the information from vehicle traffic counters where used in combination with statistical data $[7,10,11]$.

\subsubsection{Driving conditions}

Data on average speeds and annual mileage are required. For this purpose, COPERT methodology defines 3 driving conditions: urban, rural and highway driving, which are associated with different engine operation conditions (mean speed, fuel consumption), and consequently, different emission rates. Again, two different scenarios were considered:

- The allocation of the percentages of each driving conditions for regular traffic are obtained from the Joint Research Centre JRC [12]. Annual mileage varies for each category of vehicles; therefore, mean values for Spain were considered [13].

- For the highway, only the highway driving condition is applicable and mileage considered must be the length of the specific stretch of the highway.

A brief summary of information exposed is shown in Table 2:

Table 2: $\quad$ Average annual mileage and speeds for various driving conditions and different types of vehicles $[12,13]$.

\begin{tabular}{|c|c|c|c|c|}
\hline \multirow{2}{*}{ Vehicle } & \multirow{2}{*}{$\begin{array}{c}\text { Annual mileage } \\
(\mathrm{km} / \text { year })\end{array}$} & \multicolumn{3}{|c|}{ Average speed $(\mathrm{km} / \mathrm{h})$} \\
\cline { 3 - 5 } & Urban & Rural & Highway \\
\hline Passenger cars & $10659-17295$ & 30 & 67 & 118 \\
\hline LDV & $4965-11910$ & 30 & 67 & 118 \\
\hline HDV & $49453-53457$ & 14.6 & 55 & 100 \\
\hline Buses & 75902 & 20 & 55 & 100 \\
\hline Motorcycles & 1804 & 30 & 67 & 118 \\
\hline
\end{tabular}

\section{Results and discussion}

\subsection{Atlantic Highway emissions}

Application of the methodology described above over the Atlantic Highway results in the emissions shown in Table 3. These results are distributed into stretches presented in Figure 2.

From the values recorded in Table 3, the most significant emissions are associated with the longest stretches, that is H-2 (merger of the stretches from A Coruña and Ferrol), H-4 (approach to Santiago de Compostela) and H-6 (approach to Pontevedra), representing 20\%, 27\% and $21 \%$ of the total, respectively.

Nevertheless, if the results were considered in terms of the ratio emissions $/ \mathrm{km}$, the major contributions would be those corresponding to the approaches to the main cities (H-1, H-4, H-9 and R-2). 
Table 3: Emissions obtained when applying the COPERT methodology over the Atlantic Highway traffic.

\begin{tabular}{|c|c|c|c|c|c|c|c|c|c|}
\hline \multirow{2}{*}{ Stretch } & \multicolumn{10}{|c|}{ Emissions (t/year) } \\
\cline { 2 - 11 } & $\mathrm{CO}$ & NMVOC & $\mathrm{NO}_{\mathrm{x}}$ & $\mathrm{SO}_{\mathrm{x}}$ & $\mathrm{NH}_{3}$ & $\mathrm{CO}_{2}$ & $\mathrm{CH}_{4}$ & $\mathrm{~N}_{2} \mathrm{O}$ & $\mathrm{PM}$ \\
\hline $\mathrm{H}-1$ & 209 & 15 & 156 & 5 & 2 & 27176 & 1 & $<1$ & 9 \\
\hline $\mathrm{H}-2$ & 901 & 71 & 743 & 21 & 10 & 118892 & 6 & 2 & 38 \\
\hline $\mathrm{H}-3$ & 140 & 11 & 119 & 3 & 2 & 18621 & 1 & $<1$ & 6 \\
\hline H-4 & 646 & 54 & 588 & 15 & 7 & 87122 & 4 & 2 & 28 \\
\hline H-5 & 181 & 14 & 142 & 4 & 2 & 23539 & 1 & $<1$ & 7 \\
\hline H-6 & 842 & 69 & 741 & 19 & 9 & 110236 & 6 & 2 & 36 \\
\hline H-7 & 171 & 19 & 205 & 4 & 2 & 23896 & 2 & 1 & 9 \\
\hline H-8 & 113 & 9 & 93 & 3 & 1 & 14816 & 1 & $<1$ & 5 \\
\hline H-9 & 68 & 5 & 56 & 2 & 1 & 8945 & $<1$ & $<1$ & 3 \\
\hline H-10 & 43 & 3 & 36 & 1 & $<1$ & 5639 & $<1$ & $<1$ & 2 \\
\hline H-11 & 26 & 2 & 23 & 1 & $<1$ & 3394 & $<1$ & $<1$ & 1 \\
\hline R-1a & 159 & 12 & 1 & 123 & $<1$ & 2 & $<1$ & $<1$ & 7 \\
\hline R-1b & 280 & 22 & 2 & 229 & 1 & 3 & $<1$ & $<1$ & 12 \\
\hline R-2 & 201 & 15 & 156 & 5 & 2 & 26137 & 1 & $<1$ & 8 \\
\hline$\Sigma$ & 3982 & 323 & 3060 & 434 & 40 & 468420 & 24 & 9 & 169 \\
\hline
\end{tabular}

\subsection{Regular traffic within EMEP grid cells}

The results obtained with COPERT 4 for the regular traffic within the EMEP grid cells are presented in Table 4.

Table 4: $\quad$ Emissions over EMEP grid cells crossed by the Atlantic Highway.

\begin{tabular}{|c|c|c|c|c|c|c|c|c|c|}
\hline \multirow{2}{*}{$\begin{array}{c}\text { EMEP } \\
\text { cell }\end{array}$} & \multicolumn{9}{|c|}{ Emissions ( $t$ /year) } \\
\hline & $\mathrm{CO}$ & NMVOC & $\mathrm{NO}_{\mathrm{x}}$ & $\mathrm{SO}_{\mathrm{x}}$ & $\mathrm{NH}_{3}$ & $\mathrm{CO}_{2}$ & $\mathrm{CH}_{4}$ & $\mathrm{~N}_{2} \mathrm{O}$ & PM \\
\hline$(49,14)$ & 2725 & 326 & 758 & 28 & 23 & 173891 & 31 & 8 & 40 \\
\hline$(49,15)$ & 10790 & 1293 & 2783 & 120 & 93 & 686537 & 118 & 34 & 157 \\
\hline$(49,16)$ & 5290 & 638 & 1426 & 62 & 45 & 344709 & 58 & 17 & 82 \\
\hline$(49,17)$ & 5992 & 724 & 1642 & 68 & 51 & 393998 & 66 & 19 & 96 \\
\hline$(50,13)$ & 4981 & 598 & 1284 & 52 & 43 & 316842 & 55 & 16 & 72 \\
\hline$(50,14)$ & 14576 & 1751 & 3810 & 217 & 125 & 934117 & 160 & 46 & 216 \\
\hline$\Sigma$ & 44353 & 5330 & 11702 & 547 & 380 & 2850095 & 488 & 141 & 663 \\
\hline
\end{tabular}




\subsection{Contribution of Atlantic Highway to road traffic emissions}

For comparison purposes, the results presented in Table 4 were split up into their correspondent EMEP grid cell. In Table 5, the contribution (in percentage) of the highway to the total traffic emission calculated was presented:

Table 5: Contribution of highway emissions to the total emissions (regular traffic + highway traffic), expressed as a percentage.

\begin{tabular}{|c|c|c|c|c|c|c|c|c|c|}
\hline \multirow{2}{*}{$\begin{array}{c}\text { EMEP } \\
\text { cell }\end{array}$} & \multicolumn{8}{|c|}{ Contribution to total emissions $(\%)$} \\
\cline { 2 - 11 } & $\mathrm{CO}$ & NMVOC & $\mathrm{NO}_{\mathrm{x}}$ & $\mathrm{SO}_{\mathrm{x}}$ & $\mathrm{NH}_{3}$ & $\mathrm{CO}_{2}$ & $\mathrm{CH}_{4}$ & $\mathrm{~N}_{2} \mathrm{O}$ & $\mathrm{PM}$ \\
\hline$(49,14)$ & 3.8 & 2.5 & 10.2 & 8.0 & 4.9 & 7.4 & 2.2 & 3.0 & 10.1 \\
\hline$(49,15)$ & 9.7 & 6.5 & 25.0 & 18.0 & 12.3 & 18.1 & 5.9 & 7.5 & 23.6 \\
\hline$(49,16)$ & 16.3 & 11.7 & 38.8 & 28.0 & 20.0 & 28.6 & 10.7 & 13.3 & 35.1 \\
\hline$(49,17)$ & 9.9 & 6.9 & 25.6 & 18.1 & 12.4 & 18.0 & 6.3 & 7.8 & 22.3 \\
\hline$(50,13)$ & 7.5 & 5.3 & 21.7 & 15.2 & 9.1 & 14.3 & 4.9 & 6.0 & 19.2 \\
\hline$(50,14)$ & 4.1 & 3.0 & 13.0 & 6.3 & 5.2 & 8.1 & 2.7 & 3.6 & 11.3 \\
\hline
\end{tabular}

The contribution of the Atlantic Highway on the total emission has different importance according to the EMEP grid cell and pollutant considered. However, the analysis of the results can be summarised as follows:

- The emissions from the Atlantic Highway represent a relevant contribution for most of the pollutants, but especially for $\mathrm{NO}_{\mathrm{x}}, \mathrm{SO}_{\mathrm{x}}, \mathrm{CO}_{2}$ and particles. $\mathrm{SO}_{\mathrm{x}}$ emissions are overestimated as they are based on the maximum sulphur content in fuels, according to legal specifications for Spain in 2006.

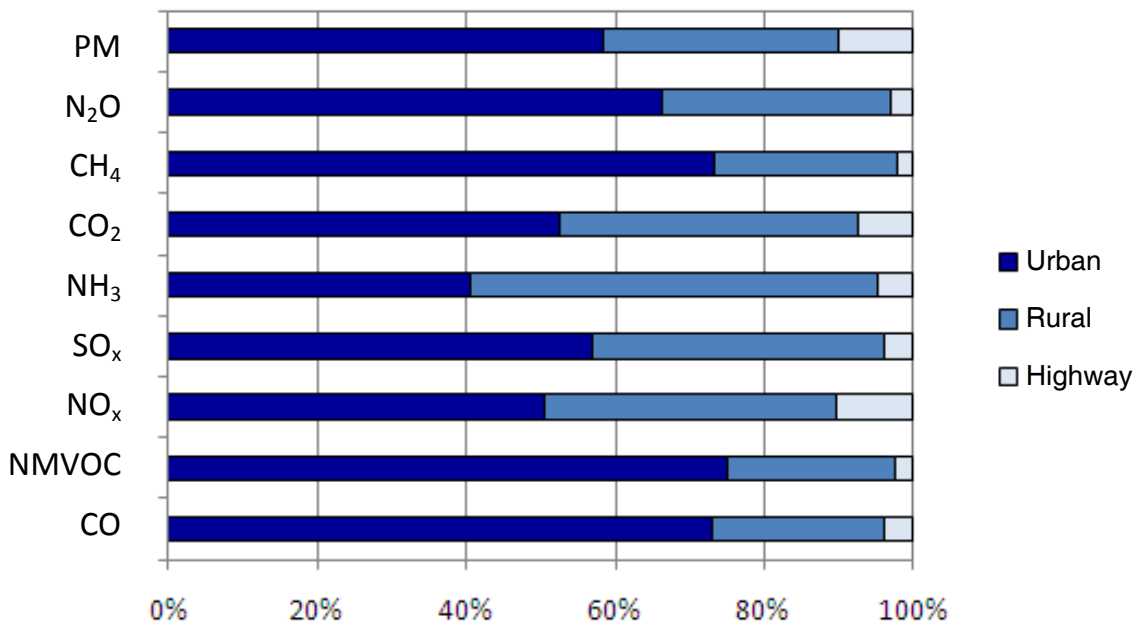

Figure 3: Distribution of the EMEP grid cell $(49,14)$ emissions according to the driving condition: urban, rural and highway for a Coruña. 


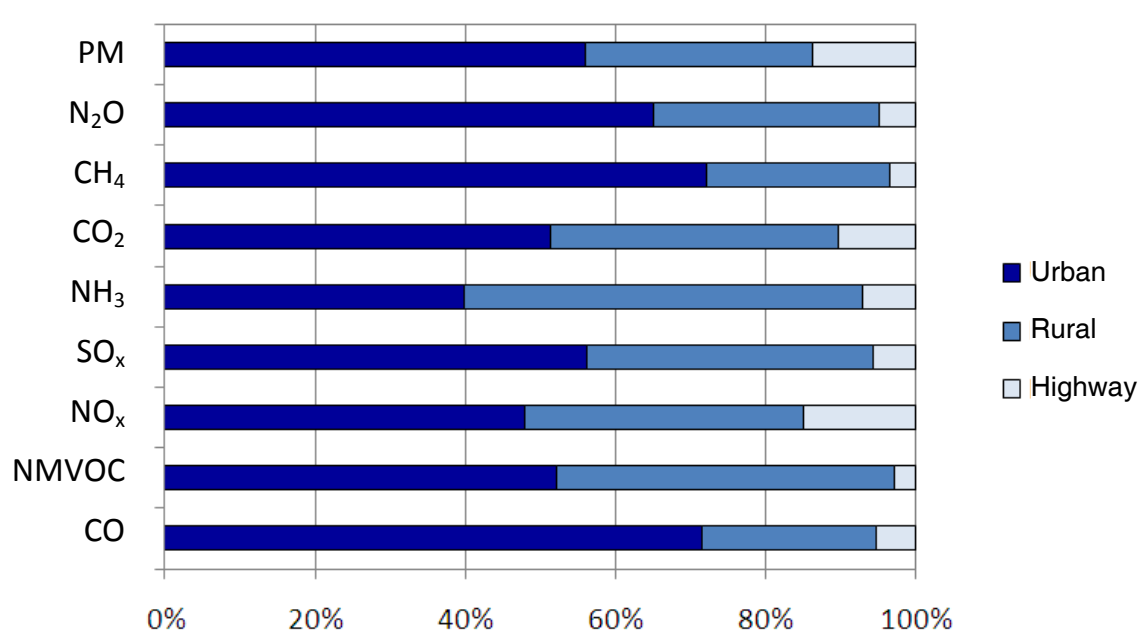

Figure 4: Distribution of the EMEP grid cell $(50,14)$ emissions according to the driving condition: urban, rural and highway for Vigo.

- The contribution of the highway is very significant for EMEP grid cell $(49,16)$, around Santiago de Compostela, due the high traffic density on the approach road to Santiago (more than 18000 vehicles per day). Within this cell, there is not any major urban development; therefore, the emissions from the highway play a decisive role.

- On the other hand, in EMEP grid cells $(49,14)$ and $(50,14)$ where the cities of A Coruña and Vigo are located, the contribution of the highway does seem to be significant; despite the high values of traffic densities observed (fig.2: over 54000 vehicles per day in A Coruña and nearly 59000 vehicles per day in Vigo). The contribution of the highway is upstaged by the emissions from urban traffic, which contributes with very high percentages, as is presented below in Figures 3 and 4.

\subsection{Comparison with EMEP data}

The comparison of the results obtained in this study with the EMEP inventory [14] allows a qualitative evaluation of their accuracy. Values close to 1 will prove the coherence of both inventories. The EMEP inventory does not cover all the pollutants included in this work, so the analysis is limited to $\mathrm{NO}_{\mathrm{x}}, \mathrm{NMVOC}$, $\mathrm{CO}, \mathrm{SO}_{\mathrm{x}}, \mathrm{NH}_{3}$ and $\mathrm{PM}$.

The calculated emissions show good coherence, since they are of the same order of magnitude than those proposed by the EMEP inventory. Major differences were observed for $\mathrm{SO}_{\mathrm{x}}$, but they are partially explained because of the overestimate of the emissions. 


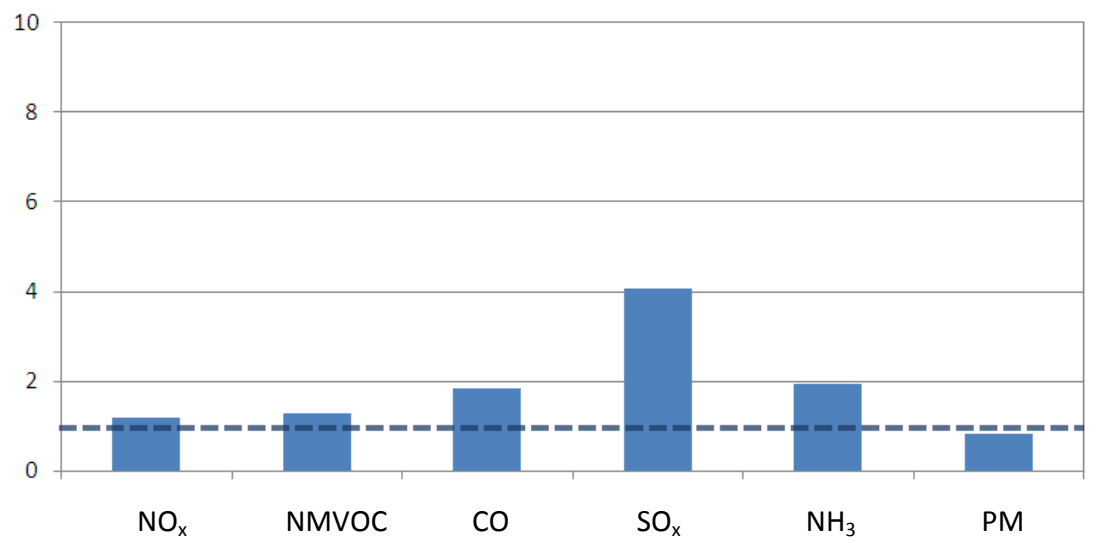

Figure 5: EMEP inventory vs. calculated emissions (regular traffic + highway).

\section{Conclusions}

Traffic emissions have a significant contribution to global emissions, especially within the approaches to the city centre, where major traffic density is concentrated. In this work, an evaluation of the emission from a highway and the surrounding area was set up by means of COPERT 4. This tool introduces a simplified methodology to calculate the emissions from road transport in general and from a specific road (Atlantic Highway).

The following conclusions are a consequence of the results obtained:

- The contribution of emissions from the Atlantic Highway to the total road emissions of the area can be quite significant, reaching percentages above $38 \%$. This is due to the contribution of the approaching stretch to the city of Santiago de Compostela and its industrial area.

- The role of a heavily jammed approaching stretch of the highway can be upstaged by the emissions of the urban traffic in the city. Therefore, further research has to be done to characterize more accurately the emissions from the traffic in cities as A Coruña and Vigo.

- The results attained with COPERT are a valid representation of the total emissions from road transport, as it was shown through the comparison with the EMEP inventory.

\section{References}

[1] EMEP/CORINAIR Emission Inventory Guidebook - 2007. Technical Report No. 16/2007. European Environment Agency EEA, 2007. 
[2] COPERT 4 (version 6.1) Computer Programme to Calculate Emissions from Road Traffic. Laboratory of Applied Thermodynamics. Aristotle University Thessaloniki. Greece, 2009. http://lat.eng.auth.gr/copert/

[3] Transport and environment: facing a dilemma. European Environment Report 3/2006, European Environment Agency, 2006.

[4] CEIP EMEP Centre on Emission Inventories and Projections, http://www.ceip.at

[5] IGE (Galician Statistical Institute) http://www.ige.eu/

[6] INE Portugal (Portuguese Statistical Institute) http://www.ine.pt/

[7] Spanish Government. Traffic Map, 2006 (CD-ROM). Ministerio de Fomento. Dirección General de Carreteras, Spain

[8] Ntziachristos, L., Samaras, Z.. COPERT III Computer programme to calculate emissions from road transport. Methodology and emission factors (Version 2.1). Technical Report No 49. European Environment Agency EEA, 2000

[9] Meteorological agency of Galicia. MeteoGalicia, http://www.meteogalicia.es/

[10] Spanish Government. Statistics in national fleet of vehicles. Public Department in charge of traffic (DGT). www.dgt.es

[11] INE Spain (Spanish Statistical Institute) http://www.ine.es/

[12] Ntziachistos L. Status of Road Transport Emissions Inventories. Join Research Centre JRC. Ispra, 2007. http://ies.jrc.ec.europa.eu

[13] Ntziachistos L. and Kouridis C. Methodologies for Transport. Report No. 08.RE.0013.v1. European Consortium for Modelling of Air Pollution and Climate Strategies EC4MACS

[14] CEIP EMEP Centre on Emission Inventories and Projections, http://www.ceip.at 